\title{
Analysing ideological complexes from the perspective of modalities
}

\section{Menard, Rusten Lyn}

2018-10-30

Menard, R L 2018, ' Analysing ideological complexes from the perspective of modalities ' , Text \& Talk , vol. 38 , no. 6 , pp. 729-751 . https://doi.org/10.1515/text-2018-0021

http://hdl.handle.net/10138/306528

https://doi.org/10.1515/text-2018-0021

submittedVersion

Downloaded from Helda, University of Helsinki institutional repository.

This is an electronic reprint of the original article.

This reprint may differ from the original in pagination and typographic detail.

Please cite the original version. 


\title{
Rusten Menard*
}

\section{Analyzing ideological complexes from the perspective of modalities}

\author{
https://doi.org/10.1515/text-2018-0021
}

\begin{abstract}
Modalities are fundamental in building, maintaining and contesting ideological systems. While modalities have been described as resources for constructing both representational and interpersonal aspects of reality and truth, the analytical focus has been on modalities as a relationship between authors, their texts and their audiences, i.e. on their interpersonal functions. Informed by a framework on modalities for discourse analyses of values, Hodge and Kress's theory on ideological complexes and Fairclough's three-dimensional conception of discourse, in this paper I develop a method for examining modalities as resources for building dominant and counter discourses. I use example excerpts that come from my research on Finnish equality discourses to build and demonstrate the method. The example texts were written by people who are differently positioned in relation to salient norms and institutions on gender/sex and sociability: people contacted through a national random sample, people diagnosed with Asperger's syndrome, and people with transgender experiences. The method allows not only for systematic examinations of how modalities function in ordering power-imbalanced interpersonal relations but also attends to an underexplored dimension dealing with how modalities work in ideological representation.
\end{abstract}

Keywords: modality, evidential, enunciation, pragmatic, epistemic, veridiction

\section{Introduction}

There have been numerous and sometimes contradictory ways of conceptualizing ideology (Eagleton 1991; Larrain 1996). Stances vary, for example, regarding where ideology is thought to be "located" - is it in texts, structures, cognition, events or somewhere else? Does ideology constitute subjects or do subjects constitute ideologies? On an empirical level, ideology can also be difficult to pin down. It seems that particular discourses and discursive practices are often named as ideological without explicating specific aspects in the research

*Corresponding author: Rusten Menard, University of Portsmouth, Park Building, King Henry 1st Street, Portsmouth P01 2DZ, UK, E-mail: rusten.menard@port.ac.uk 
material that make them so. There is a lack of methodological guidance, specifically with respect to analyzing representational aspects of ideologies. Nevertheless, because of their fundamental status in relations of domination, social researchers using critical discursive approaches take ideologies as focal in their work.

In critical discourse studies, modality has been of ideological interest because it concerns claims to knowledge, authenticity and truths (Fairclough 1989: 126-129). Fairclough argues that dialectical relations between representational and interpersonal (actional and identificational) meanings are "particularly clear in the case of modality" (Fairclough 2003: 166). He characterizes modality as a point of intersection in discourse between representation and the enactment of social relations, linking it to the interpersonal function of language (Fairclough 1992: 158-160). In social semiotics, modality has been theorized as relevant to both representational and interpersonal realms of constructions of reality and truth (e.g. Van Leeuwen 2005: 160). Yet in both critical discourse studies and social semiotics, modal analyses of ideology have focused on linguistic modality as a matter of relations between authors, their texts and their audiences, i.e. on its interpersonal function.

Informed by a sociosemiotic framework on modalities for discourse analyses of values (Sulkunen and Törrönen 1997a), Hodge and Kress's (1988) theory on ideological complexes, and Fairclough's (e.g. Fairclough 1992) three-dimensional conception of discourse, in this article I develop a method for analyzing ideological systems from the perspective of modalities. In line with social semiotic and critical discursive approaches, I understand modality as concerning author commitments to truth, reality and knowledge, as well as author expressions of necessity, desire, ability and competency. Expressions of modality thus build on ontological status, epistemic certainty, speaker images, interpersonal solidarity and distance, as well as representational aspects of values, identifications and ideologies. I emphasize the idea that modality concerns both interpersonal and representational aspects of power-dominant and antagonistic social ordering. Working on the claim that modalities work in different dimensions of discourse, I also stress that analyzing them as such is beneficial in social analyses of ideology.

In Section 2, I work towards these aims by building the theoretical framework for the method, and by discussing the social semiotic theory of modality and ideological complexes. In Section 3, I describe the study from which the example excerpts that I use in developing the method come. Section 4 comprehensively develops the method through the use of illustrative empirical analyses, in which the focus is on ideological Finnish equality discourses, and by integrating Fairclough's three-dimensional model of discourse. 


\section{Towards a framework for analyzing ideologies: modalities as resources for orientation in the interpersonal realm and representation}

Social semiotic and critical discourse analytic explications of ideology typically proceed from post-Marxist accounts, where ideology is considered socially and psychologically constitutive. Gramsci (1988: 199) considered historically organic ideologies as necessary to given psychologies and social structures. Ordering the social sphere by forming the terrain upon which individuals move and become aware of their positions, ideologies are seen as constituting individuals. Gramsci described commonsense knowledge as resulting from previous ideological struggles, as well as continuously targeted for transformation in ongoing ideological processes (see Fairclough 1992: 92). Althusser (1971) took ideology as a system of representations with a historical function that "hails" the subject to establish a relationship with it. Establishing relationships with ideologies is part of socialization and developing cultural competency. Ideology both originates in and produces social relations that are connected to dominant relations of production. Ideology is thus also material for Althusser, functioning through the production of subject positions (Hall 1988: 48).

In critical discourse studies, ideologies are systems of ideas that explain particular political and social orders, legitimate hierarchies and preserve group identities (Chiapello and Fairclough 2002). While implicated in the works of Gramsci and Althusser, Fairclough explicitly locates ideology in both structures and events (e.g. Fairclough 1992: 88-89): ideologies are representations that contribute to relations of domination, are "enacted" in ways of acting socially (e.g. etiquette, genres), and are "inculcated" in identities (Fairclough 2003: 9 , 218). In social semiotics, ideologies are generally characterized as systematic bodies of ideas and representations of "reality" and "truth," which are based upon previous ideas and representations, and organized from a particular point of view (e.g. Kress and Hodge 1979). An emphasis in social semiotics is that the content of ideological systems is seen as controlled by modality (Hodge and Kress 1988: 122-124).

Social semiotic and critical discursive approaches to modality can usually be traced back to the work of Halliday (e.g. Halliday and Matthiessen 2004: 618-621), who divides the modality system into two general categories. "Modalizations" function to express authorial stance on propositions, in terms of probability and usuality. "Modulations" work on the thesis of the clause by establishing intermediary degrees in proposals, in terms of 
obligation and inclination (Halliday 1970: 336-338). Qualifications of ability are described as being "on the fringe of the modality system" (Halliday and Matthiessen 2004: 621).

The semantic system consists of three primary metafunctions for Halliday (1978: 128-151): ideational, interpersonal and textual. The ideational function pertains to representational modes of meaning in texts. The interpersonal function concerns modes of meaning enacted in social interactions, in interaction with the content of communication, and in interaction with external voices and discourses. The textual function manages interactions between interpersonal and ideational meanings, giving text coherence and relevance to context. One of the ways that interpersonal meanings are embodied grammatically is in modalizations. Ideational meanings can be realized grammatically in some modulations (Halliday 1970: 336-338).

Let us look at how expressions of Halliday's modality system unfold in Excerpt (1), below. ${ }^{1}$

(1) (R77, female from random sample)

Minorities bring "enrichment" to our country and teach people to understand each other better, because the situation requires that they must know how to be dealt with. On the other hand, minorities may even be perceived as a threat to the country's essence, and therefore also a kind of a negative stamp is possible. The problem may also be language barriers, which means that everywhere Sami language isn't necessarily understood. While Muslims could be thought of as "offensive" to Finnish Christianity.

"Requires" and "must" can be taken as (deontic) modulations that build ideational meaning. They work on the thesis of the clause in terms of perceived necessity. "Know how" also pertains to ideational meaning, and can be interpreted as modulating ability or internalized know-how. Two instances of "may", "possible", "not necessarily" and "could be" are interpretable as functioning interpersonally, elevating and distancing the author from the utterances they qualify.

Sulkunen and Törrönen (1997a: 50-51) argue that as regards analyzing values, Halliday's conception of modality is too narrow in that the semantic function is confined to building solidarity and distance between authorial voices and their audiences. Values are constructed modally in utterances in which interpersonal modal structures are only implicit, for example when uttering

1 The examples that I use in this paper come from an empirical study dealing with equality discourses (Menard 2016); the details about data and methodology are outlined in Section 3. 
subjects do not explicitly include themselves in their texts. In storylines there is inevitably interaction between the interpersonal and ideational planes that involves evaluating the world being discussed. They consequently propose an analytical distinction between modalities that function interpersonally, and those that function to qualify and position classifications in storylines on the ideational plane. They refer to these as enunciative and pragmatic modalities, respectively (Sulkunen and Törrönen 1997a, Sulkunen and Törrönen 1997b).

Enunciative modalities function interpersonally in qualifications of truth and quality of knowledge. Resources of enunciative modality are used to build speaker images and interpersonal relations, and for positioning oneself and others in relation to contents of communication. Pragmatic modalities function in ordering representation, as classifications are positioned relationally towards action-oriented goals. Pragmatic modalities qualify obligation, permission, ability and competence, and work on formulating, evaluating and structuring representational contents.

The roles of some enunciative modalities (e.g. epistemic modality) in building interpersonal solidarity and distance have been stressed in critical linguistically informed methodologies. The concept of enunciative modality nevertheless allows for further consideration as regards how qualifications of ontological status may do ideological work. I also attend to an underexplored dimension dealing with how pragmatic modalities can function ideologically. Working on the claim that enunciative and pragmatic modalities function collaboratively, I argue that ideological social relations are built with reference to previous ideological representations around similar topics, as well as to update, maintain and transform them. I thus take ideological social relations and representations as mutually determinate. Without a study of both enunciative and pragmatic modalities, important dimensions of ideological work and the dialectical relations between them are potentially left under examined, underexposed and less available to criticism.

\subsection{Enunciative modalities: evaluating epistemic knowledge and states of the world}

Enunciative modalities position speakers/writers and their audiences in relation to each other, and in relation to the representations in their texts. There are two types of enunciative modalities: epistemic modalities qualify certainty of knowledge, while veridictory modalities work on comparing how the world appears with speakers'/writers' knowledge of how the world actually is (Sulkunen and Törrönen 1997a, Sulkunen and Törrönen 1997b; Törrönen 2003: 309). 
Epistemic modality works in realms of believing and knowing, and in constructing the quality of knowledge unfolding in the utterance. Expressions of epistemic modality qualify speakers'/writers' certainty relative to what they are discussing, from the position of the addressee. This understanding of epistemic modality corresponds to critical linguistic accounts, and to what Halliday refers to as modalizations. The knowledge constructed with epistemic modal expressions can be, for example, certain, doubtful, assumptive or imaginary. Epistemic modalities hierarchically order the social sphere by positioning authors and their audiences. Yet they can also build alliances by, for example, constructing text producers as competent and legitimate possessors of knowledge that addressees can trust.

Veridictory modality works in realms of appearing and being. Veridictory qualifications evaluate states of the world by comparing appearances with reality. In taking up veridictory stances, authors disclose illusions (something appears like this, but is really not like that), secrets (we are sure that this thing exists, but it has not yet appeared) or errors (we tried to see something until we realized that it does not exist) regarding that which is being discussed, or confirm that the truth is in line with how it appears to our senses. Veridictory modalities can function to position the addresser and addressee into the same viewpoint by reporting and commenting upon what the world looks like to anyone observing it. By placing addressers and addressees on the same footing and building motivation in the addressee to follow the argument, veridictory modalizations work on solidarity between authors and audiences. They are persuasive and are used in rhetorical texts, constructing reader positions by offering competencies to identify with speakers' and writers' viewpoints.

One way that veridictory modality is realized grammatically is through evidential expressions. Evidentials reference speakers'/writers' sources of knowledge, such as direct observation, inference, reporting and hearsay (e.g. Chafe 1986; Van Dijk 2014: 259). They indicate how the speaker/writer "has come to know what they are claiming" (Hart 2011: 758). Veridictory modality is also realized in less explicit ways, for example by working with logic and argumentation in the building of storylines. Let us look at Excerpt (2), which I analyze in terms of how epistemic and veridictory modalities build speakerimages and reader positions.

(2) (R53, respondent with transgender experiences)

I don't necessarily believe in social classes, but sometimes I feel like I don't have the same human rights, because I experience my gender/sex differently than [the way] society defines it. Also my economic situation is weak, and I haven't received the support that I need for it. 
"Believe" can be taken as an expression of epistemic modality that builds uncertain knowledge about social class. "Sometimes" modalizes usuality, working to further build uncertainty by qualifying the stability of knowledge about equivalent human rights. The expressions "feel" and "experience" are interpretable as evidential markers that work on solidarity, inviting readers to evaluate the state of the world from the author's viewpoint. The speaker-image becomes more confident in these lines, while the last half of the text is uttered with full certainty. A trustworthy speaker-image can be interpreted as culminating through collaborative work with evidentials and shifts in epistemic knowledge. The initial uncertainty as regards social class transforms into legitimate knowledge about the "truth" of unequal distributions of rights and resources.

Veridictory and epistemic modalities work together to arouse emotions, build motivation in the audience to adopt a stance, establish confidence between authors and audiences, and produce positive self-images (Sulkunen and Törrönen 1997b: 122). They also imply each other: if an author "points out that some argument is epistemically assumptive, he/she makes room for the advent of another kind of ontological view of it" (Törrönen 2003: 310; cf. Papafragou 2006). Enunciative modalities are relevant to analyses of ideology because they work on interpersonal solidarity and distance. They function in ordering the social sphere by persuading the audience to take up the positions being offered.

Accounts of "epistemic stance" in critical discourse studies overlap with the concept of enunciative modality. Epistemic stance is characterized as acts "aimed at the legitimization of the assertions, through the expression of speaker/writer's degree of certainty regarding the realization of the event and/ or the reference to the sources and modes of access to that knowledge" (MarínArrese 2015a: 211). Among the tools for accomplishing epistemic stance are epistemic modalizations and evidentials. The resources of epistemic stance can serve ideological purposes by managing the validity of the communicated information, and by persuading audiences to adopt authors' viewpoints (Marín-Arrese 2015b: 262).

\subsection{Pragmatic modalities: positioning participants in representation into action-oriented roles}

The ideological relevance of pragmatic modalities has been theoretically and methodologically underemphasized and underdeveloped. This may be partially due to the theory of pragmatic modality being informed by Greimas's (e.g. Greimas 1983 [1966], Greimas 1987) actant model, which has fallen out of 
fashion due to its structuralism. The concept of pragmatic modality is nevertheless useful, from my standpoint, for analyzing how power imbalanced social relations intrude representation to build ideological systems of classifications and networks of meanings. Pragmatic modalizations function in utterances to relationally position classifications of actions, humans and non-humans into participant roles that are differently valued.

Participant roles include subjects and anti-subjects, objects and anti-objects, helpers and opponents, and senders and receivers. Subjects express modalities of volition or inclination that specify wanting-to (desire, passion, willingness) elements of action towards obtaining value objects. Anti-subjects qualify wanting-to elements of their own objects, functioning as antagonists to subjects' action programs. Helpers activate modalities that qualify being-able-to (abilities and situational resources) and knowing-how-to (acquired and internalized competencies and skills) aspects of action that are needed for subjects to obtain objects, while opponents activate modalities of not-being-able to (inabilities) and not-knowing-how-to (incompetencies) aspects that are necessary for anti-subjects to obtain their own objects (anti-objects). Senders and receivers work to activate and legitimize subjects' actions towards obtaining objects, expressing deontic modalities of having-to (obligation, compulsion, command, interdiction, permission, prohibition) elements of action (Sulkunen and Törrönen 1997a; see also Törrönen 2001, Törrönen 2014).

In Excerpt (2), "need" is interpretable as an expression of compulsion or volition, with "support" as the qualified object and "I" as subject and notrecipient. Having "the same human rights" and economic equity can be taken as assumed values (see Fairclough 2003: 57, 173). Thus, although they can have linguistic markers, pragmatic modalities may also be realized implicitly. Text producers may rely on audiences to understand the assumptions and common knowledge upon which "successful" receptions of their utterances are based. Because assumptions rely on inference, analysis of ideologies from the perspective of pragmatic modality should not be undertaken solely at the linguistic level. I will return to Excerpt (2) in Section 4.

\subsection{Modality and ideological complexes}

Elaborating on a term used by Gramsci (1971) in his prison notebooks, Hodge and Kress (1988) refer to the interdependent oppositional representations of particular aspects of reality as ideological complexes. Ideological complexes are sets of contradictory representations that are imposed by one social group on another on behalf of its own interests, or subversively offered by another 
group in line with its own interests. In ideological complexes, social reality is represented as serving the interests of both the dominant and the dominated. By constraining behavior based upon those representations, they function to sustain relationships of subordination and antagonism.

Successful functioning of ideological complexes relies on "logonomic systems," or sets of "rules prescribing the conditions for production and reception of meanings" (Hodge and Kress 1988: 4). Ideological complexes are inscribed in logonomic systems which express ideological content by controlling semiosis. They rely on visibility to function, for example through etiquette or legislation. Text producers rely on their audiences having specific knowledge of a logonomic system in order to "correctly" receive and interpret their messages. When unchallenged, logonomic systems ensure that productions and receptions of texts serve to maintain positions of the dominant. When structures of domination are undergoing challenge, logonomic systems are also likely being contested. Messages are received in ways that producers may not have intended such as with suspicion or doubt - or are explicitly rejected. Logonomic systems imply a theory of social order, a theory of knowledge, and a theory of modalities (Hodge and Kress 1988: 5).

For Hodge and Kress (1988: 122-124), modality is restricted to expressions of affinity with utterances and refers to constructions and contestations of knowledge systems. Following Halliday, they describe modality as a matter of interpersonal relations, while modal forms are traces of those relations. Particular expressions of modality "code" particular states of the plane of representation at the particular time of their occurrence; they are effects of the semiosic plane (interpersonal realm) projected onto the mimetic plane (representations). As with other signs, the meanings and effects of modal signs are embedded historically and socially.

Important to my aims in this article is that in this social semiotic account of ideology, modality is specified as the site where ideological systems are imposed and contested. Social control depends on authority over which representation of reality is accepted as the grounds for evaluation and action. This may be indirect control of representations through modality. "Whoever controls modality can control which version of reality will be selected out as the valid version in that semiosic process" (Hodge and Kress 1988: 147). Social control may also lie in direct control of representational content, through selections and qualifications of classifications. This means of social control, however, is underexplored in social semiotic theory. It is here that the concept of pragmatic modality can contribute to analyses of ideological complexes.

Hodge and Kress argue that ideological complexes consist of "relational models (classifications of kinds of social agent, action, object, etc.) and actional 
models (specifications of actions and behaviors required of, permitted or forbidden to kinds of social agent)" (Hodge and Kress 1988: 3). In my reading of this statement and in terms of Sulkunen and Törrönen's typology of modalities, we can think of ideological complexes as classifications that are recurrently positioned into relational participant roles with pragmatic modalities.

Analyses of pragmatic and enunciative modalities have been useful in my interpretations of ideological complexes and logonomic systems on Finnish equality. One such system is that which regulates proper social interaction styles. Some of the rules in this logonomic system link ordinariness and moderation to equal sociability, whereas distinctions, "standing out" and dissenting voices are seen as inegalitarian (Menard 2016, Menard 2017; see also Törrönen and Maunu 2005). Modal analyses have been beneficial in examining how this logonomic system provides the conditions for discursively excluding Others, while detracting attention away from illogic that may inhabit the logonomic system itself. These are some of the ways in which ideological complexes survive (cf. Blackledge 2002).

My own understanding of ideology thus proceeds from that of Hodge and Kress, precisely due to their interrelated theory on modality and ideological complexes. I nevertheless claim that modality concerns the "doubly determined," mutual effects of representational and interpersonal ideological meanings. Ideological structures provide the conceptual backdrop for ongoing ideological work. I therefore approach ideologies as, firstly, interpersonal relations of domination that are formulated and updated in expressions of enunciative modality. Secondly, ideologies are systems of relational, contradictory and competing representations, which consist of participant roles that are imbued with content and relationally positioned using pragmatic modal resources.

\section{Materials and methods}

The example excerpts come from an empirical and methodological critical discourse research project on social values, ideology and Finnish equality (Menard 2017). My research interests include how being explicitly "marked" as psychiatrically, medically or socially "abnormal" might interact with negotiations of equality. Study respondents included people differently positioned in relation to institutionalized norms on gender/sex and/or sociability: people contacted through a national random sample $(n=240)$, people with Asperger's diagnoses $(n=24)$, and people with transgender experiences $(n=40)$. The example excerpts 
result from written tasks that were conducted with informed consent: respondents were asked to give and explain their opinions on eight basic, open questions dealing with perceptions of oneself and others in Finnish society, the social structure and the state. ${ }^{2}$ Discourse and modal analyses were conducted on original Finnish responses. The excerpts in this article were translated with the aim to convey my readings of the functions and meanings produced in the original Finnish texts, particularly as regards expressions of modality. Full methodological details are available in published empirical articles (Menard 2016, Menard 2017).

\section{Analyzing ideological complexes from the perspective of modalities}

In this section I demonstrate some ways in which analyses of ideological complexes from the perspective of enunciative and pragmatic modalities might proceed. In the examples I also account for different levels of analysis. Failing to do so ignores the question as to how expressions of modality are relevant to ideological macro structures.

A useful framework is Fairclough's (e.g. Fairclough 1989: 25-26, Fairclough 1992: 73-100) three-dimensional model of discourse, which corresponds to three levels in critical discourse analyses; those of text, discursive practices and social practices. Approaching discourse as text involves analyses of lexicalization, grammar and text structure, for example. Analyses at the textual level are the most descriptive, sticking closely to the utterance, image or whatever type of text is being analyzed. Because meaning productions also rely on audience interpretations and because ideological processes are interpersonal, analyses of ideologies cannot be solely at the textual level. In analyses at the level of discursive practices, focus areas include the force and coherence of utterances, and traces of intertextuality and interdiscursivity in texts. This dimension mediates between the textual and social dimensions of discourse. In approaching discourse as social practice, the analysis is focused on the extent to which texts

2 The specific questions were: Are people basically the same or basically different?; What types of people and groups of people do you like and what types do you not like?; What are the advantages or disadvantages of minorities living in Finland (for example, the Sami, Swedishspeaking Finns, homosexuals, Muslims)?; What are Roma beggars doing in Finland?; Please complete the following sentence in your own words: The social structure in Finland is ...; Is the Finnish state fair?; Does everyone have equal opportunities to realize their goals?; Do you see yourself belonging to any social strata, classes, segments or other such groups? 
are ideologically invested; whether or not they sustain relations of domination. This is the explanatory, "critical" aspect of the analysis. The boundaries between these three dimensions are fluid, overlapping, and analyses should move dialogically between them rather than linearly.

\subsection{Analyzing hegemonic discourses from the perspective of modalities}

Let us reconsider Excerpt (1). This time the focus is on ideological traces in the text from the perspective of enunciative and pragmatic modalities in three dimensions of discourse. Grammatically and in terms of enunciation, the first two lines of Excerpt (1) are unmodalized assertions. "Understanding each other better" and "enrichment" can be interpreted as value assumptions, requiring that audiences have the "common knowledge" necessary to "correctly" understand them. "Enrichment" is also placed inside quotation marks. This grammatical marker can be interpreted at the level of discursive practices as an allusion to veridictory logic built in the rest of the text. Evidentials work on building this logic: minorities being "perceived" as a threat; Sami language not being "understood"; and Muslims being "thought of" as offensive. The epistemic modalizations noted in the preliminary analysis of this text (Section 2) can be interpreted as hedges, functioning to distance the speaker-image from the socially undesirable utterances that they qualify.

These aspects of Excerpt (1) reference patterns in the corpus (see Menard 2016, Menard 2017) that can be considered in interpretations of ideological investment at levels of discursive and social practices: Pertaining to instantiations of a dominant discourse on equal sociability in which tolerance and equality are networked, respondents usually begin their texts with unelaborated assertions in which classifications of "minorities" and "enrich" co-occur. A quarter of these respondents then reposition, aligning with marginal yet exclusionary discourses. In these shifts there are often declines in epistemic certainty that can be interpreted as working on distancing respondents from politically incorrect stances. Despite the declines and distancing, minorities' value is overall implicated as ontologically illusory or untrue. The veridictory logic built in the pattern can be interpreted as building an argument that "although we often hear (appearance) that minorities enrich culture, some ways we think their contributions are negative, illusory or non-existent (being) are (a, b, c ... )." Excerpt (1) exemplifies this veridictory logic that is patterned and redundant in the corpus. These patterns and redundancies were taken into account in my 
interpreting particular instantiations of the dominant discourse on equal sociability as ideologically invested.

The shifts in interpersonal positioning and epistemic certainty in Excerpt (1) are paralleled in representation. As with enunciative modalities, the researcher can interpret how recurring pragmatic modalizations work on building hierarchical relations between participant roles in the realm of representation. Grammatically, "minorities” temporarily occupy a participant role of subject. At the level of discursive practices, their primary value is as helpers in actions on assumed social values of "enrichment" and "teaching people to understand each other better”. Minorities are primarily of instrumental value, while aspects dealing with intrinsic worth go unrecognized. They are carriers of diversity and messengers of tolerance to "our country" and "people" (recipients).

The deontic modalization "must" can be taken as constructing a social obligation (in which there are no agents) for "knowing how they are to be dealt with" - for obligatory tolerance. Minorities then become anti-subjects in actions on the country's essence, with "country" as the sender. The Sami are implicated as anti-subjects in action goals on "being understood", with Sami language as an opponent. Muslims are positioned as opponents to Finnish Christianity. Interpreted at the level of social practices and in relation to the entire corpus, the implication in these modalizations is that these minorities' difference is threatening: tolerating minorities is obligatory; social recognition and equal participation of those who signify "difference" are seemingly problematized. I will further discuss my interpretations of ideological investment at the level of social practices in Excerpt (1), shortly.

Excerpt (3), ${ }^{3}$ below, is a good example of how modalizations can function to build relations of domination by qualifying or implicating some resource, ability, competency or characteristic as an ontologically true and definitive aspect of who "we" are.

(3) (R232, male from random sample)

Finland is a democracy where people live in peace and their basic needs are mostly taken care of. Health care, education etc. common necessities are mostly equal.

Yes, essentially [the Finnish state is fair]. Freedom and peace are focal. Peace $=$ no war. Freedom $=$ the right to equality and responsibility.

In principle, [there are] pretty good opportunities for studying and health care, for example. There's room for improvement. The international

3 Excerpt (3) consists of responses to three consecutive questions, separated here by hard returns and space between lines. 
capital/monetary economy infringes upon equality and freedom in Finland as well.

Storylines are built on multiple assumptions and assertions and without explicit markers of epistemic modality, positioning the writer in high solidarity with the network of classifications in the text. Two instances of "mostly" and "pretty" can be interpreted at levels of discursive and social practices as hedges that function to position the author as not entirely lacking knowledge of inequalities. These hedges are important for building a competent speaker-image in a social context where media, political and lay discourses on "increasing inequalities" are pervasive. "Taken care of", "essentially", "in principle” and "there is room for improvement" can be interpreted as veridictory modalizations that work rhetorically in evaluating equality and freedom as "true" aspects of Finland's social structure that are "obscured" by international forces. Interpreted at the level of discursive practices, public services and primary school are implicated as being ontologically true abilities - as existing and available helpers that reveal the essence of Finnish equality.

The "truth" of Finnish equality and freedom is built correspondingly with structures of representation, as resources that characterize the nation. The "right to" and "opportunities" can be taken as modalizing ability, qualifying resources that help maintain equality and freedom. Interpreted at levels of discursive and social practices, these helpers reference a logonomic system that regulate discourses on Finnish "equality contracts". The helpers in this discourse are overall usually qualified as true, true as possible, or true when making international comparisons, and as evidenced by their status as "universal" rights and provisions of the welfare state (Menard 2016, Menard 2017). The clearest agent comes in the last sentence, positioning "global capitalism" as an anti-subject with its own trajectory to interdict ("infringe") Finnish equality and freedom. As an incoming force, this modalization can be taken as functioning to mask and legitimize power imbalancing and material unequalizing processes within Finnish borders. There seems to be "a perfect fit between the system of classification and the objects which that system describes: a relation which seems at once transparent, natural, and inevitable" (Hodge and Kress 1988: 122). In terms of social practices, Excerpt (3) speaks to previous research in terms of how entangled discourses on the Nordic model and equality are seen as exceptional, are central in nation-building, and work ideologically (Trägårdh 2002; Kuisma 2007).

Analyzing enunciative and pragmatic modalities at different levels of discourse can also be helpful for unravelling how rules of logonomic systems are embodied in discursive practices. Excerpt (4), below, unfolds similarly to 
Excerpt (1), particularly in terms of how pragmatic modalizations function to position representational content into relational participant roles. Both excerpts begin by drawing on networks of hegemonic discourses on diversity and tolerance in producing socially acceptable, assertively uttered, trustworthy speakerimages.

(4) (R255, female from random sample)

Minorities are enriching for Finland and they teach the majority to accept different people. Nowadays it's gone a bit overboard when they demand rights so vigorously (the homosexuals) and some Muslims don't understand that "when in Rome, do as the Romans do".

Similarly to the previous excerpt, Excerpt (4) provides an interesting example of how relations of domination can be interpreted from texts that lack explicit epistemic modal markers. An analysis of Excerpt (4) conducted exclusively at the level of text, as regards how enunciative and pragmatic modalizations work on investing the utterance ideologically, is not possible.

However, at the level of discursive practices, pragmatic modalizations can be interpreted as occurring by drawing on ideological discourses related to diversity and tolerance, to which they also contribute back. Although there are indicators of qualifications of competence in this text (e.g. "teach"), the pragmatic modalizations seem to rely on the audience having "common knowledge" for "correctly interpreting" participant roles. Pragmatic modality works in the first sentence by implicating and drawing from diversity discourses to qualify minorities as enriching resources of "difference." They are instrumental for the majority in learning to "accept different people", and for the respondent to perform tolerance.

At the level of social practices, this common feature of Excerpts (1) and (4) may be considered as ideologically invested when analyzed in relation to the entire corpus and the sociocultural context. In relation to the discourse that they draw upon and build, minorities and immigrants are recurrently qualified as "helpers" who "bring" the "difference" or "diversity" that is needed for the majority to learn tolerance (Menard 2016, Menard 2017). As helpers, their value tends to be instrumental and their agencies deflated. This interpretation resonates with earlier arguments and research claims: Finnish culture is predominantly understood as being "previously homogenous"; multiculturalism perceived as coming from the outside and introducing significant differences to it; and the two phenomena are seen as interdependent (Tuori 2007). Also similar to Excerpt (1), the positioning of minorities into helper roles in Excerpt (4) is interpretable as an expression of modality that 
functions in saving face. The rest of the response is devoted to undoing minorities' helper positioning.

"Nowadays" can be taken as signaling an ontological distinction between the idea of minorities as helpers in teaching acceptance, and the present "reality". At the level of discursive practices, this veridictory modalization works to rhetorically position the putative audience into the here-and-now, power-dominant viewpoint of "Finland" and "the majority". The ontological specification intrudes representation, as the respondent negatively orients to and projects excessive demands for (equal) rights onto the viewpoints of homosexuals. At the level of social practices these modalizations can be interpreted as building homosexuals as incompetent in moderation and positioning them as opponents to majority performances of acceptance. A similar projection of incompetence in Finnishness onto the viewpoints of Muslims can be read from the excerpt, positioning them as additional opponents to tolerance by the majority. A modalization of obligation is implicated by the metaphor "when in Rome, do as the Romans do" ("maassa maan tavalla"), which can be taken as contributing to assimilationist discourses. Apart from delineating the respondent's stance, Excerpt (4) falls in line with another redundancy in the corpus: expressions of pragmatic modality work on positioning Muslims, immigrants and minorities into participant roles of anti-subject and opponent in entangled discourses on tolerance and equality (on the ideology of tolerance, see, e.g. Brown 2006; Žižek 2008).

\subsection{Analyzing counter-hegemonic discourses from the perspective of modalities}

Ideological complexes also include counter discourses that can be approached from the perspective of modality. While researchers may interpret patterns in the study material in terms of how modalities are used in domination and subjugation, in other parts of the corpus they may also notice modal qualifications and logic that function in opposing or subverting those patterns.

My previous analysis of pragmatic modalizations in Excerpt (2) (Section 2.2) is of limited relevance for research on ideology. I interpreted value assumptions in the text, implicating intertextuality (Fairclough 2003: 57, 173). By considering how pragmatic modalities work intertextually/interdiscursively in building storylines, their potential functions in representational aspects of ideological complexes become clearer. At the level of discursive practices, Excerpt (2) can be interpreted as produced in interaction with welfare society discourses related to social class, human rights, gender equality, economic equity and public goods. 
These discourses are drawn upon in reiterating a societal obligation to provide support for those who face economic hardships, with society the sender of support. It is also possible to interpret "not believing in social classes" and "having the same human rights" as assumptions about what is socially desirable or necessary. Gender equality can be interpreted as a helper of equal human worth. Taking "weak economic situation" as an assumed anti-object, "economic equity" can also be interpreted as an object of value that is formulated in this text, with "support" as its helper.

In my analysis of enunciative modalities in Excerpt (2) at the textual level (Section 2.1), I focused on how the text works on building a trustworthy speaker-image through evidentials and shifts in epistemic knowledge. At the level of discursive and social practices, veridictory argumentation can be interpreted as interacting with external discourses that claim Finnish equalities as truths. The logic built is that what appears from the viewpoint of society as social classlessness does not exist from the viewpoint of the respondent. Interpreting the analyses together with that of pragmatic modalities, the logic can be expressed in the following way: Although Finland may appear to be classless or relatively equal, this is an ontological illusion as evidenced by the human rights violations (forced sterilization of people seeking transgenderrelated healthcare) and socioeconomic statuses of gender non-conforming people. At the level of social practices, Excerpt (2) can be interpreted as being produced in opposition to hegemonic discourses that seem conceptually linked to historical national projects that focused on dissolving class distinctions and culminated in building the welfare state (Häkkinen and Tervonen 2004).

Let us look at the final Excerpt (5), which was produced in response to two consecutive questions. The excerpt exemplifies how modalities can function in opposing an equality that is inclusive of obligations to conformity, moderation and sameness.

(5) (R18, female with Asperger's diagnosis)

People are evened out and different people are marginalized according to the ideal of normality. This is not done openly but with unspoken agreements etc. Certain matters of support are more concrete, for example the laws on caring for close relatives are not followed.

No. [People do not have equal opportunities.] Sociability has too much meaning, people are not always openly informed even about official things. If you want to live your life your way, but others think it's a weird way, few people want to support it. Instead, if you want to become what else does society demand of us? 
The text is epistemically assertive and in low solidarity with the classification system on equality. Epistemic modality works on building a confident speakerimage in opposition to marginalization and normalization processes, concluding with an epistemic modalization in the form of a question. This is interpretable as functioning to position both the writer and audience as subjects in action, leaving the reader with an implicit call to make a choice about participating in marginalization and normalization processes (cf. Törrönen 2003). "This is not done openly" and "people are not openly informed" build veridictory logic that provides the audience with further tools for correctly receiving that call to action. In arguing for the invisible mechanisms of hegemonic social values of normativity, the author asks the reader to become aware of the ontological secrets that dictate marginalization of the evening out processes that exist (being) but "are not done openly" (not appear).

The interpersonal runs parallel to how the level of representation transpires. At the level of discursive practices, normality can be taken as a presupposed ideal and societal obligation. Pragmatic modalizations can be interpreted as organized around the will for individuality and freedom on the one hand, and prohibitions and social undesirability of doing things non-normatively on the other. In referencing discourses on normativity, the participant role of subject is interpretable as occupied by others, people and society, with society as the sender. The respondent constructs individuality and social support as personal desires against societal obligations to normalize.

Excerpts (2) and (5) are arguably produced against dominant discourses on Finnish equality, building counter discourses that are helpful for interpreting their hegemonic counterparts (Menard 2016, Menard 2017). Interpreted at the level of social practices, texts that modalize discourses on Finnish equality as illusory or false are over twice as frequently uttered with less epistemic certainty than those that modalize it as ontologically true. Secondly, as regards Aspergerdiagnosed respondents, differences are typically modalized as existing (being) but as unrecognized (appearing) or permitted in the dominant order. Here, pragmatic modalizations function in efforts to dislodge difference from its naturalized positioning as opponent or anti-subject, and reposition it into helper or subject roles. This pattern also recurs, although less frequently, in texts produced by those with transgender experiences. At the level of social practices, these patterns can be interpreted as indicative of ideological complexes. Respondents questioning the truth of hegemonic discourses are required to do so from divergent, non-normative and marginal standpoints. Antagonistic stances can thus act as openings for comparative interpretations of relational hegemonic and counter discourses. In order to call hegemonic discourses into question, one must first recognize and re-present them. 
Thus, although insufficient in that they cannot account for the historical movement of ideas in society, social position and material factors are logical points of entry for analyses of ideology (Hall 1988: 45). Subjugated positions are not innocent and should not be exempt from critical analyses. Yet people who inhabit them are often aware of the "tricks" that comprise hegemonic knowledge and ontological "truths", such as the "modes of denial through repression, forgetting, and disappearing acts; ways of being nowhere while claiming to see comprehensively” (Haraway 1988: 584). Such situated knowledges can be insightful in analyses of ideology.

\section{Conclusion}

The above empirical examples resonate with claims in social semiotic theory that analyses of epistemic modality are useful for unravelling how solidarity and distance transpire in social events. I have additionally emphasized the role of veridictory modality in interpersonal ideological work, which can function rhetorically to compare appearances with "reality." By positioning audiences into "our” viewpoints, veridictory and epistemic modality work together in stabilizing and disrupting what is taken to be "true" and "real."

One of my primary aims in this article has been to call attention to how pragmatic modalities can function ideologically. Pragmatic modal analyses can focus on ways in which ideological complexes are continuously referenced in reconstituting social orders; on whether and how text productions contribute to, update, call into question and restructure power-imbalanced commonsense knowledge. This is important because ideological complexes persist as artifacts, providing the historical backdrops that are referenced in ongoing ideological social practices. While I agree that studying what is done with representations is imperative, prioritizing ideological practices in analyses without comprehensively examining ideological structures is unnecessary. Efforts might also be directed at understanding how structures and processes are mutually constitutive; the dynamics between them; and how they can be analyzed as such. This is the approach I underscore in this article.

Analyzing pragmatic modality at the levels of text, discursive practices and social practices is helpful for understanding how power-imbalanced social relations intrude representation and, reciprocally, how those representations are drawn upon in ongoing social ordering and constructions of social reality. At the levels of text and discursive practices, pragmatic modalities delineate representations of 
social order by qualifying and evaluating elements in utterances, i.e. by positioning classifications into participant roles that are differently valued. At the level of discursive practices, the analysis can focus on how pragmatic modal resources function intertextually and interdiscursively; the work they do as hegemonic discourses are drawn upon, updated and transformed. At this level, pragmatic modalities build storylines by inference to "commonsense" knowledge.

Analyses at the level of social practices can be directed at how those qualifications and inferences to common knowledge are patterned across texts; the order of discourses they reference and contribute back to; and the extent to which they sustain or reformulate relations of domination. Researchers may want to integrate quantitative methods in support of claims to hegemonic, marginal or counter-hegemonic statuses of patterns in the corpus. Frequency counts can be cited, for example, of particular styles of enunciative stance in instantiations of particular discourses, or of particular pragmatic modalizations that qualify particular participant roles in instantiations of particular discourses. For dealing with large amounts of texts, a corpus-assisted approach may supplement the modal analyses (cf. Baker 2012).

Also relevant to the level of social practices are archival and historical analyses, and previous research. Patterned modalizations do not come from nowhere. They should be traceable by investigating the cultural historical contexts in which the redundancies occur. Interpreting patterns at the level of social practices is important in understanding whether, and how, discursive practices are ideologically invested; how ideologies have transformed and show continuity. Analyses of ideological complexes at the level of social practices may also involve considering the extent to which counter discourses are displacing or being consumed by hegemonies. During times of social transformation or upheaval, an ideology can be an ontological truth to some, and an illusion or falsity to others. Antagonism can have an effect not only upon its truth value but also upon the formulation and transformation of ideological meanings. Logonomic systems can and do face contestation. This is accomplished with both enunciative and pragmatic modalities.

Acknowledgements: This research has been supported by the Kone Foundation (Koneen Säätiö), a Finnish Doctoral Program in Social Sciences (SOVAKO) and the Doctoral Program in Social Sciences at the University of Helsinki. Special thanks go to Jukka Törrönen for commenting on multiple versions of this paper. I would also like to thank Inari Sakki, Gordon Sammut, Srikant Sarangi, Satu Venäläinen and three anonymous reviewers for their helpful feedback and suggestions on previous versions of this work. 


\section{Appendix: respondents' original textual responses}

(1) Vähemmistöt tuovat "rikkautta" maahamme ja opettavat ihmisiä ymmärtämään toisiaan paremmin, sillä heihin pitää osata suhtautua tilanteen vaatimallattavalla. Toisaalta vähemmistöt voidaan kokea jopa uhkana maan perusolemukselle, ja näin ollen myös tietynlainen kielteinen leima on mahdollinen. Ongelmana voi olla myös kielimuurit, eli kaikkialla ei välttämättä ymmärretä esim. saamen kieltä. Muslimien taas voitaisiin ajatella "loukkaavan" Suomen kristinuskoa.

(2) En välttämättä usko yhteiskuntaluokkiin, mutta joskus minusta tuntuu, ettei minulla ole samoja ihmisoikeuksia, koska koen sukupuoleni eri tavalla kuin yhteiskunta sen antaa määrittää. Myös taloudellinen tilanteeni on heikko, enkä ole saanut siihen tarvitsemaani tukea.

(3) Suomi on demokratia, jossa ihmiset elää rauhassa ja perustarpeista enimmäkseen huolehditaan. Terveydenhoito, koulutus jne. yleistarpeet on enimmäkseen tasa-arvoisia.

Kyllä, olennaisilta osin. Vapaus ja rauha ovat keskeisiä. Rauha = ei sotaa. Vapaus = oikeus tasa-arvoon ja vastuu.

Periaatteessa melko hyvät mahdollisuudet esimerkiksi opiskeluun ja terveydenhuoltoon. Parantamisen varaakin on. Kansainvälinen pääoma/rahatalous rikkovat tasa-arvoa ja vapautta myös Suomessa.

(4) Vähemmistöt ovat rikastuttavia Suomelle ja opettavat enemmistölle erilaisten ihmisten hyväksymistä. Nykyään tämä on mennyt vähän yli kun he vaativat oikeuksia niin voimakkaasti (homoseksuaalit) ja jotkut muslimit ei ymmärrä "maassa maan tavalla".

(5) Ihmisiä tasapäistetään ja erilaiset marginalisoidaan normaaliuden ihanteen mukaan. Tätä ei tehdä avoimesti vaan sanattomin sopimuksin yms. Konkreettisempia ovat tietyt tukiasiat, esim. lakeja omaishoidosta ei noudateta. Ei. Sosiaalisuudella on liikaa merkitystä, virallisistakaan asioista ei aina tiedoteta avoimesti. Jos haluaa elää omannäköistä mutta muiden mielestä outoa elämää, harvat haluavat tukea sitä. Sen sijaan, jos haluaa normalisoitua - mitäpä muuta yhteiskunta meiltä edellyttää?

\section{References}

Althusser, Louis. 1971. Ideology and ideological state apparatuses. In Louis Althusser (ed.), Lenin and philosophy and other essays, 127-186. London: New Left Books. 
Baker, Paul. 2012. Acceptable bias? Using corpus linguistics methods with critical discourse analysis. Critical Discourse Studies 9(3). 247-256.

Blackledge, Adrian. 2002. The discursive construction of national identity in multilingual Britain. Journal of Language, Identity, and Education 1(1). 67-87. 10.1207/ S15327701)LIE0101_5.

Brown, Wendy. 2006. Regulating aversion: Tolerance in the age of identity and empire. Princeton: Princeton University Press.

Chafe, Wallace. 1986. Evidentiality in English conversation and academic writing. In Wallace Chafe \& Johanna Nichols (eds.), Evidentiality: The linguistic coding of epistemology (Advances in discourse processes 20), 261-272. Norwood: Ablex.

Chiapello, Eve \& Norman Fairclough. 2002. Understanding the new management ideology: A transdisciplinary contribution from critical discourse analysis and new sociology of capitalism. Discourse \& Society 13(2). 185-208.

Eagleton, Terry. 1991. Ideology: An Introduction. New York: Verso.

Fairclough, Norman. 1989. Language and power. Essex: Longman.

Fairclough, Norman. 1992. Discourse and social change. Oxford: Polity Press.

Fairclough, Norman. 2003. Analyzing discourse: Textual analysis for social research. London: Routledge.

Gramsci, Antonio. 1971. Selections from the prison notebooks. New York: International Publishers.

Gramsci, Antonio. 1988. The Antonio Gramsci reader. Selected writings 1916-1935. London: Lawrence and Wishart.

Greimas, Algirdas J. 1983 [1966]. Structural semantics: An attempt at a method. Lincoln: University of Nebraska Press.

Greimas, Algirdas J. 1987. On meaning: Selected writings in semiotic theory. Minneapolis, MN: University of Minnesota Press.

Häkkinen, Antti \& Miika Tervonen. 2004. Ethnicity, marginalization and poverty in the twentieth century Finland. In Vesa Puuronen, Antti Häkkinen, Anu Pylkkänen, Tom Sandlund \& Reetta Toivanen (eds.), New challenges for the welfare society, 22-39. Joensuu: Joensuun yliopisto.

Hall, Stuart. 1988. The toad in the garden: Thatcherism among the theorists. In Cary Nelson \& Lawrence Grossberg (eds.), Marxism and the interpretation of culture, 35-57. Chicago: University of Illinois Press.

Halliday, Michael A. 1970. Functional diversity in language as seen from a consideration of modality and mood in English. Foundations of Language 6(3). 322-361.

Halliday, Michael A. 1978. Language as social semiotic. London: Edward Arnold.

Halliday, Michael A. K. \& Christian M. Matthiessen. 2004. An introduction to functional grammar. 3rd ed. London: Hodder Education.

Haraway, Donna. 1988. Situated knowledges: The science question in feminism and the privilege of partial perspective. Feminist Studies 14(3). 575-599.

Hart, Christopher. 2011. Legitimizing assertions and the logico-rhetorical module: Evidence and epistemic vigilance in media discourse on immigration. Discourse Studies 13(6). 751-814.

Hodge, Robert \& Gunther Kress. 1988. Social semiotics. New York: Cornell University Press.

Kress, Gunther \& Robert Hodge. 1979. Language as ideology. London: Routledge \& Kegan Paul.

Kuisma, Mikko. 2007. Social democratic internationalism and the welfare state after the 'golden age'. Cooperation and Conflict 42(1). 9-26.

Larrain, Jorge. 1996. Stuart Hall and the Marxist concept of ideology. In David Morley \& Kuan-Hsing Chen (eds.), Stuart Hall: Critical dialogues in cultural studies, 46-70. London: Routledge. 
Marín-Arrese, Juana I. 2015a. Epistemicity and stance: A cross-linguistic study of epistemic stance strategies in journalistic discourse in English and Spanish. Discourse Studies 17(2). 210-225.

Marín-Arrese, Juana I. 2015b. Epistemic legitimation and inter/subjectivity in the discourse of parliamentary and public inquiries. Critical Discourse Studies 12(3). 261-278.

Menard, Rusten. 2016. Doing equality and difference; representation and alignment in Finnish identification. Text \& Talk 36(6). 733-755. 10.1515/text-2016-0032.

Menard, Rusten. 2017. Critical discourse studies on social values, ideology and Finnish equality. Helsinki: Publications of the Department of Social Research.

Papafragou, Anna. 2006. Epistemic modality and truth conditions. Lingua 166. 1688-1702.

Sulkunen, Pekka \& Jukka Törrönen. 1997a. The production of values: The concept of modality in textual discourse analysis. Semiotica 113(1-2). 43-70.

Sulkunen, Pekka \& Jukka Törrönen. 1997b. Constructing speaker images: The problem of enunciation in discourse analysis. Semiotica 115(1-2). 121-146.

Törrönen, Jukka. 2001. The concept of subject position in empirical social research. Journal for the Theory of Social Behaviour 31(3). 313-329.

Törrönen, Jukka. 2003. On the road to serfdom? An analysis of Friedrich Hayek's socio-political manifesto as a pending narrative. Social Semiotics 13(3). 305-320.

Törrönen, Jukka. 2014. Situational, cultural and societal identities: Analysing subject positions as classifications, participant roles, viewpoints and interactive positions. Journal for the Theory of Social Behaviour 44(1). 80-98. 10.1111/jtsb.12029.

Törrönen, Jukka \& Antti Maunu. 2005. Going out, sociability and cultural distinctions. Nordisk Alkohol-och Narkotikatidskrift 22. 24-43.

Trägårdh, Lars. 2002. Sweden and the EU: Welfare state nationalism and the spectre of “Europe". In Lene Hansen \& Ole Wæver (eds.), European integration and national identity : The challenge of the Nordic states, 130-181. London: Routledge.

Tuori, Salla. 2007. Cooking nation: Gender equality and multiculturalism as nation-building discourses. European Journal of Women's Studies 14(1). 21-35.

Van Dijk, Teun A. 2014. Discourse and knowledge. A sociocognitive approach. Cambridge: Cambridge University Press.

Van Leeuwen, Theo. 2005. Introducing social semiotics: An introductory textbook. London: Routledge.

Žižek, Slavoj. 2008. Tolerance as an ideological category. Critical Inquiry 34. 660-668.

\section{Bionote}

\section{Rusten Menard}

Rusten Menard is a social and critical psychology lecturer in the Sociology Unit at the University of Portsmouth, UK. He has a PhD in Social Sciences from the University of Helsinki, Finland, where he also teaches methodological courses on a part-time basis. His research interests include social values, identification, critical discursive studies on motivation and affect, qualitative methodologies, and discourse and social transformation. 